\title{
Spawning and early development of the West Indian top shell, Cittarium pica (Linnaeus, 1758), under ex-situ conditions
}

\author{
Luz A. Velasco* and Judith Barros \\ Laboratorio de Moluscos y Microalgas, Universidad del Magdalena, Carrera 2 No 18-27, Taganga, Santa Marta, Colombia
}

Received 15 March 2017 / Accepted 23 May 2017

Handling Editor: Pauline Kamermans

\begin{abstract}
The West Indian top shell, Cittarium pica, is an endangered vetigastropod from the rocky intertidal Caribbean. In order to provide a basis for its hatchery-production as a conservation tool, spawning and early development were evaluated under ex-situ conditions. Spawning response was monitored during different lunar phases with application of physical and chemical stimuli - such as changes in temperature salinity and desiccation, exposure to UV irradiated water and chemical stimulation with Tris and hydrogen peroxide. Spawning response was obtained in association with daytime, new moon, flooding and high tides. Use of physical and chemical stimuli did not elicit any spawning response. Adults conditioned in the hatchery for one year did not spawn. Spawning of males and females was simultaneous and frequently intermittent. On average, percentage and size of spawn was higher for males than females. Fecundity was positively correlated with total female wet weight, with an average value of 149000 oocytes per female. Embryonic and larval development was reported in detail. Results suggest that there is a high potential to use the controlled ex-situ reproduction of $C$. pica as a conservation tool, since gamete and larvae were repeatedly obtained from wild adults collected days before new moon following a circadian endogenous pattern applying simple protocols of spawning, fertilization and incubation.
\end{abstract}

Keywords: Reproduction / Hatchery / Embryonic development / Tegulidae

\section{Introduction}

The West Indian top shell, Cittarium pica, is a marine herbivorous, detritus feeder vetigastropod, which inhabits the rocky intertidal zone of the Caribbean region (Randall, 1964). It is a dioecious broadcast spawner, without noticeable external sexual dimorphism; fertilization is external, and larvae are lecitotrophic (Bell, 1992). Populations exhibit sexual ratios close to $1: 1$, with mean size at sexual maturity ranging from 58 to $68 \mathrm{~mm}$, and a continuous reproductive cycle with higher proportion of spawning animals reported in May, and between July and October (Randall, 1964; Bell, 1992; Osorno and Díaz, 2006; Osorno and Gil, 2009; Toro et al., 2009). C. pica is considered to be one of the most important gastropods in the region due to its ecological and commercial value. It acts as one of the major algae growth-controllers as well as suppliers of shelters for hermit crabs, food for predators (fishes, octopus, muricids, lobsters and birds) and substrata for epibionts in the Caribbean rocky intertidal and reef ecosystems (Randall, 1964; Robertson, 2003; Osorno and Sanjuan, 2009).

\footnotetext{
* Corresponding author: molmarcol@gmail.com
}

Since ancient times, $C$. pica has been heavily harvested as a source of traditional food and material for crafts (Osorno and Díaz, 2006; Rosique et al., 2008). As a consequence of the high fishing pressure, this species is overexploited, and has a serious risk of extirpation and/or local extinction (Debrot, 1990; Ardila et al., 2002; Robertson, 2003). Restocking activities using hatchery-produced juveniles are among the main actions proposed for the conservation of C. pica (Bell, 1992; Osorno et al., 2009). These kinds of programs have been successfully achieved with other endangered mollusks, including Trochus niloticus (Clarke et al., 2003; Purcell and Cheng, 2010) and Margaritifera margaritifera (Preston et al., 2007; Thomas et al., 2010). The first step in achieving juvenile hatchery production is to gain an understanding on its spawning cycle and larval development.

In some vetigastropods, spawning can be induced by exogenous stimuli such as changes in temperature (Chen, 1984; Holyoak, 1988; Hanh, 1989a; Clare, 1990; Setyono, 2006), salinity (Dobson, 1997), desiccation (Setyono, 2006), gametes from other individuals (Hanh, 1989a; Kulikova and Omel'yanenko, 2000), UV-irradiated water (Kikuchi and Uki, 1974; Uki and Kikuchi, 1984; Setyono, 2006) or additions of Tris, and hydrogen peroxide (Morse, 1984; Moss et al., 1995). 
Other species show endogenously controlled spawning related with the cycles of the moon, light, tides and/or typhoons (Heslinga and Hillmann, 1981; Bell, 1992; Counihan et al., 2001; Onitsuka et al., 2007, 2010). In C. pica, spawning lunar periodicity has been suggested (Bell, 1992), but it has not been confirmed.

On the other hand, the embryonic and larval development of broadcast spawner vetigastropods is very similar. The embryonic stage begins with the expulsion of the polar bodies and is completed with intra-capsular trochophore larva formation; the larval stage finishes when the crawling veliger develops the fourth tubule on the cephalic tentacles (Heslinga and Hillmann, 1981; Holyoak, 1988; Hanh, 1989b; Courtois De Viçose et al., 2007; Guzmán del Próo et al., 2011). The embryonic and larval development of $C$. pica was described by Bell (1992) but it is incomplete and does not provide photographic records. The present study was carried out in order to evaluate the ex-situ spawning response of $C$. pica, as well as to describe its early development in detail as a basis for its hatchery-production conservation tool.

\section{Materials and methods}

\subsection{Obtaining and maintaining of broodstock}

At least 100 individuals of $C$. pica (shell length $=77.6 \pm$ $9.5 \mathrm{~mm}$, tissue wet weight $=165.6 \pm 65.2 \mathrm{~g}$ ) were obtained from fishermen monthly during May, June and September 2010, and every week from March to August 2012, at the beach of Taganga Bay, Santa Marta, Colombia (Lat. $11^{\circ} 16^{\prime} 04^{\prime \prime}$ N, Long. $74^{\circ} 11^{\prime} 36^{\prime \prime}$ $\mathrm{W})$. The tides in the region are semi-diurnal with a tidal range of approximately $0.5 \mathrm{~m}$ (IDEAM, 2011). Average sea surface temperature in the region varied between 23 and $34{ }^{\circ} \mathrm{C}$, and salinity ranged from 31 to $36 \mathrm{ppt}$ (Vivas-Aguas et al., 2012). The snails were transported in humid conditions to the Laboratory of Molluscs and Microalgae of the University of Magdalena, located nearby in Taganga Bay (Lat. $11^{\circ} 16^{\prime} 03^{\prime \prime} \mathrm{N}$, Long. $\left.74^{\circ} 11^{\prime} 24^{\prime \prime} \mathrm{W}\right)$. Each snail was cleaned of epibionts, dried, marked, measured, weighed and placed among humid sponges in dark conditions. After $24 \pm 12 \mathrm{~h}$, animals were placed in $200 \mathrm{~L}$ rectangular tanks (30-60 animals tank $\mathrm{k}^{-1}$ ) containing a flow through of Taganga Bay seawater $\left(63 \% \mathrm{~h}^{-1}\right)$ aerated and filtered $(1 \mu \mathrm{m})$; at $27 \pm 1^{\circ} \mathrm{C}$ and salinity of $35 \pm 1 \mathrm{ppt}$. Specimens collected in 2010 were maintained under these conditions for 2 weeks in order to assess any spontaneous spawning. In contrast, animals obtained in 2012 were used for spawning induction experiments, and were maintained under these conditions for only $1 \mathrm{~h}$ prior to spawning experiments. The last batch of 100 animals (August 2012) was conditioned for up to 12 months in order to achieve peak reproductive status prior to spawning. For this conditioning batch, specimens were distributed in 3 outdoor tanks $(2000 \mathrm{~L})$ with a flow-through of $50 \mu \mathrm{m}$, aerated seawater $\left(1.2 \% \mathrm{~h}^{-1}\right)$, at a temperature of $29 \pm 2{ }^{\circ} \mathrm{C}$ and salinity of $36.5 \pm 0.5$ ppt. Tank walls were cleaned with seawater at high pressure and water was changed completely once per day. Animals were fed daily to satiation, with a mix of natural and artificial biofilms growing on PVC plates $(16 \mathrm{~cm} \times 21 \mathrm{~cm})$. Two types of biofilms were prepared by suspending the plates in aquaria with benthic diatom cultures (Cylindrotheca sp., Navicula sp. and Nitzschia sp.) for 8 days (referred to as natural biofilms), and impregnating clean plates in a hot mix of wheat flour $\left(30 \mathrm{mg} \mathrm{ml}^{-1}\right)$, gelatin $\left(15 \mathrm{mg} \mathrm{ml}^{-1}\right)$, agar $\left(10 \mathrm{mg} \mathrm{ml}^{-1}\right)$, as well as pulverized $(<1 \mathrm{~mm})$ dry eggshell $\left(35 \mathrm{mg} \mathrm{ml}^{-1}\right)$, algae (Spirulina sp. and Padina gymnospora $1: 1 \mathrm{w})\left(30 \mathrm{mg} \mathrm{ml}^{-1}\right)$, and squid meat $\left(15 \mathrm{mg} \mathrm{ml}^{-1}\right)$ (referred to as artificial biofilms). Microalgae cultures were prepared with $50 \mu \mathrm{m}$ filtered seawater and F/2 media culture (Guillard, 1975).

\subsection{Spawning}

Spontaneous gamete release was monitored in specimens collected in 2010 , by checking both the broodstock tanks, and the $150 \mu \mathrm{m}$ sieves installed in the tank drains (four times per day). Day and time of spawning was recorded and related to the lunar and tidal cycles. These observations were continued over a period of 2 weeks, after which animals were returned to the natural environment.

With animals collected between March and August 2012, spawning was induced during each of 4 moon phases (new, waxing, waning and full moon) and using 5 different stimuli: (1) rapid hourly increases and decreases in water temperature (T), ranging from 18 to $30^{\circ} \mathrm{C}$; (2) rapid increases and decreases in water salinity (S), ranging from 25 to $35 \mathrm{ppt}$ on an hourly basis; (3) desiccation (D), with alternative 1-h periods of immersion and emersion; (4) exposure to UV irradiated water (UV); and (5) addition of Tris $1.5 \mathrm{mM}, \mathrm{pH} 9.1$ (Carlo Erba ${ }^{\circledR}$ hydroxymethyl aminomethane) and hydrogen peroxide $\left(\right.$ Merck $\left.^{\circledR}\right)$ to the water $(\mathrm{T}+\mathrm{HP}, 8.2 \mathrm{mM})$. Three replicate aquaria $(10 \mathrm{~L})$ were set up for each treatment, including one control treatment without stimuli; each aquarium contained 6 randomly selected snails, and each treatment was repeated at least 3 times using different and new animals each time. Aquaria were maintained in darkness (lights off), with $1 \mu \mathrm{m}$ filtered, aerated and static seawater at $35 \pm 1 \mathrm{ppt}$ salinity (except those in the salinity treatment) and $27 \pm 1^{\circ} \mathrm{C}$ (except those in the temperature treatment). The stimulation period was $4 \mathrm{~h}$ and animals were observed for an additional $4 \mathrm{~h}$ following stimulation. For each replica, the percentage of spawned animals was determined as the number of individuals that released male or female gametes out of the total number of snails in the tank. Response time to the stimulus was measured from the beginning of stimulation to the initiation of gamete release, noted by the presence of sperm (white cloudy water) or oocytes (green granules on the bottom). After the spawning trials, adults were returned to the rectangular tanks for no more than 1 week, for post-induction monitoring and they were then released into the natural habitat.

Spontaneous spawning of animals conditioned for 12 months starting in August 2012 was monitored similarly as described above for the 2010 experiment. In addition, adults were also stimulated to spawn during four different times of year (October, January, May and August 2013) using UV stimuli.

\subsection{Fecundity, fertilization and early development}

Snails which began spawning were removed and placed into individual $1.6 \mathrm{~L}$ containers with $1 \mu \mathrm{m}$ filtered seawater. The total number of oocytes was counted once a female completed spawning; fecundity was estimated by counting triplicate $1 \mathrm{ml}$ samples using a Sedgewick-Rafter counting 
chamber under a light microscope. Sperm and oocytes produced within $1 \mathrm{~h}$ of each other were crossed, adding $5 \mathrm{ml}$ of sperm per container, and gently aerating the egg solution with a stirring paddle. The proportions of unfertilized and fertilized oocytes (showing polocytes or cleavage) were determined after $10 \mathrm{~min}$ of gamete contact by differential counting of samples $(1 \mathrm{ml})$ in a Sedgewick-Rafter chamber. If the percentage of fertilization was less than $90 \%$, additional spermatozoa solution was added to the oocyte chambers until reaching $100 \%$ fertilization. Samples were discarded from the culture vessels.

Fertilized eggs were distributed into plastic aquaria $(10 \mathrm{~L})$ filled with a thin layer of seawater covering the bottom surface. Zygotes were cleaned repeatedly (10 times each $15 \mathrm{~min}$ ), allowed to decant, and supernatant was removed; fresh seawater with the same characteristics as described above was added to replace the supernatant. Clean zygotes were incubated in the same aquaria with UV-treated, $1 \mu \mathrm{m}$ filtered seawater, and maintained at $25 \pm 1{ }^{\circ} \mathrm{C}$, salinity of $36 \pm 1 \mathrm{ppt}$ and under darkness conditions. After $6 \mathrm{~h}$, once hatching was complete, trochophore larvae were recovered by collecting the supernatant water in new $10 \mathrm{~L}$ aquaria. Dead and lethargic larvae observed on the bottom of the aquaria were discarded. After $16 \mathrm{~h}$, live veliger larvae were collected following the same procedure described above for trochophore larvae.

For three different spawning events, water samples $(1-10 \mathrm{ml})$ were taken with a pipette every $5 \mathrm{~min}$ for the first $40 \mathrm{~min}$, then every $45 \mathrm{~min}$ for the next $4 \mathrm{~h}$, and finally every

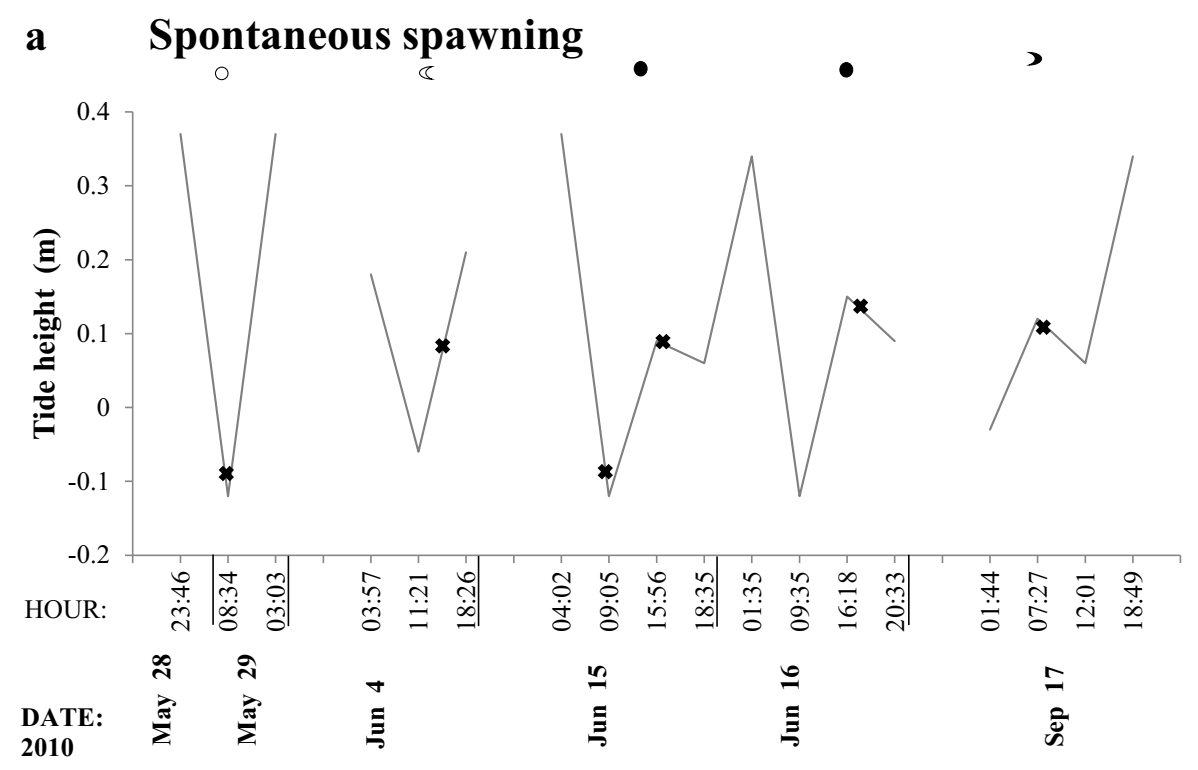

\section{b Induced spawning}
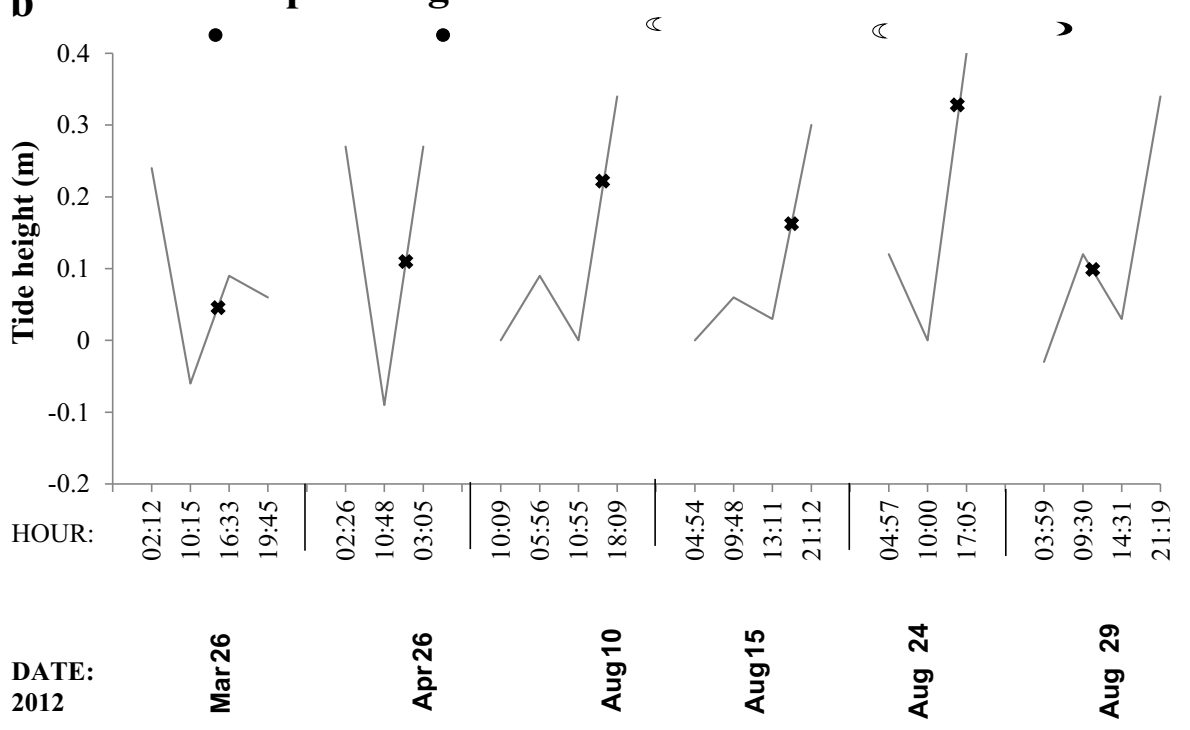

Fig. 1. Cittarium pica. Relationships among the spontaneous and induced spawning of adults recently collected with the tidal height regimen and moon phase in the Santa Marta region, Colombian Caribbean for 2010 and 2012 (IDEAM, 2009, 2011). O: New moon, ๑: full moon, ৫: waning moon, $\mathbf{~}$ : crescent moon. 
hour and $12 \mathrm{~h}$ until the post-torsional veliger and spat stages were reached, respectively. Animals were observed and photographed with a light microscope and a total of 12 embryos or larvae from each sample were measured for shell length using an ocular micrometer. Samples were discarded from the culture vessels.

\subsection{Statistical analysis}

Spawning frequencies obtained in each of the lunar, daily and tidal period were compared using the chi square test. Percentage of spawned individuals was analyzed with respect to snail sex, moon phases, and spawning stimuli, using factorial analysis of variance (ANOVA), followed by Tukey multiple comparison tests. The response times of gamete release in males and females using different spawning stimuli were compared using a two-way ANOVA. Correlation analysis was done between the weight and size of the females and their assessed fecundity. In order to compare the weight and size of spawning males and females, one-way analysis of variance followed by Tukey multiple comparison tests were applied. The normality and homoscedasticity of all the mentioned response variables were previously examined and in order to fulfill those assumptions, some variables were transformed. Percentages of spawned animals were transformed to square root, and shell length of spawning animals was transformed to logarithm. The statistical analyses were carried out following Zar (1999) and using Statgraphics Centurion Software ${ }^{\circledR}$; statistical significance decisions were based on an $\alpha$ value of 0.05 .

\section{Results}

\subsection{Spawning response}

Spawning only occurred in wild specimens, held under exsitu conditions between 1 and 10 days. Although specimens maintained under ex-situ conditions for a longer period (between August 2012 and August 2013) exhibited higher survival values $(90 \%)$, no spawning response was obtained.

A total of 12 spawning events of $C$. pica were obtained in this study (Fig. 1). Six of them were spontaneous (in May, June and September 2010, Fig. 1a) and the remaining 6 were obtained from the 16 spawning-induction treatments (between March and August 2012, Fig. 1b). Highest frequencies of spawning events were obtained in association with daytime $(11 / 12)\left(X^{2}=16.7, \mathrm{df}=1, p=0.000\right)$, flooding or high tide $(10 /$ 12) $\left(X^{2}=10.7, \mathrm{df}=1, p=0.0011\right)$ and new moon $(5 / 12)$ $\left(X^{2}=38.1, \mathrm{df}=3, p=0.000\right)$ (Fig. 1).

The percentage of males and females of $C$. pica releasing gametes varied between 0 and $33 \%$ (Fig. 2). The percentage of specimens spawning was not affected by the induction stimuli $(\mathrm{df}=5, F=1.59, p=0.1675)$, but it was significantly influenced by the moon phase $(\mathrm{df}=3, F=38.07, p=0.000)$, sex $(\mathrm{df}=1, F=13.09, p=0.004)$, and the interaction of the last two factors $(\mathrm{df}=3, \quad F=9.26, \quad p=0.000)$. Significantly more spawnings were obtained during the new moon phase, especially in males (Fig. 2d).

The response time of gamete release from the start of the stimulation varied between 5.5 and $8.0 \mathrm{~h}$ in males and females
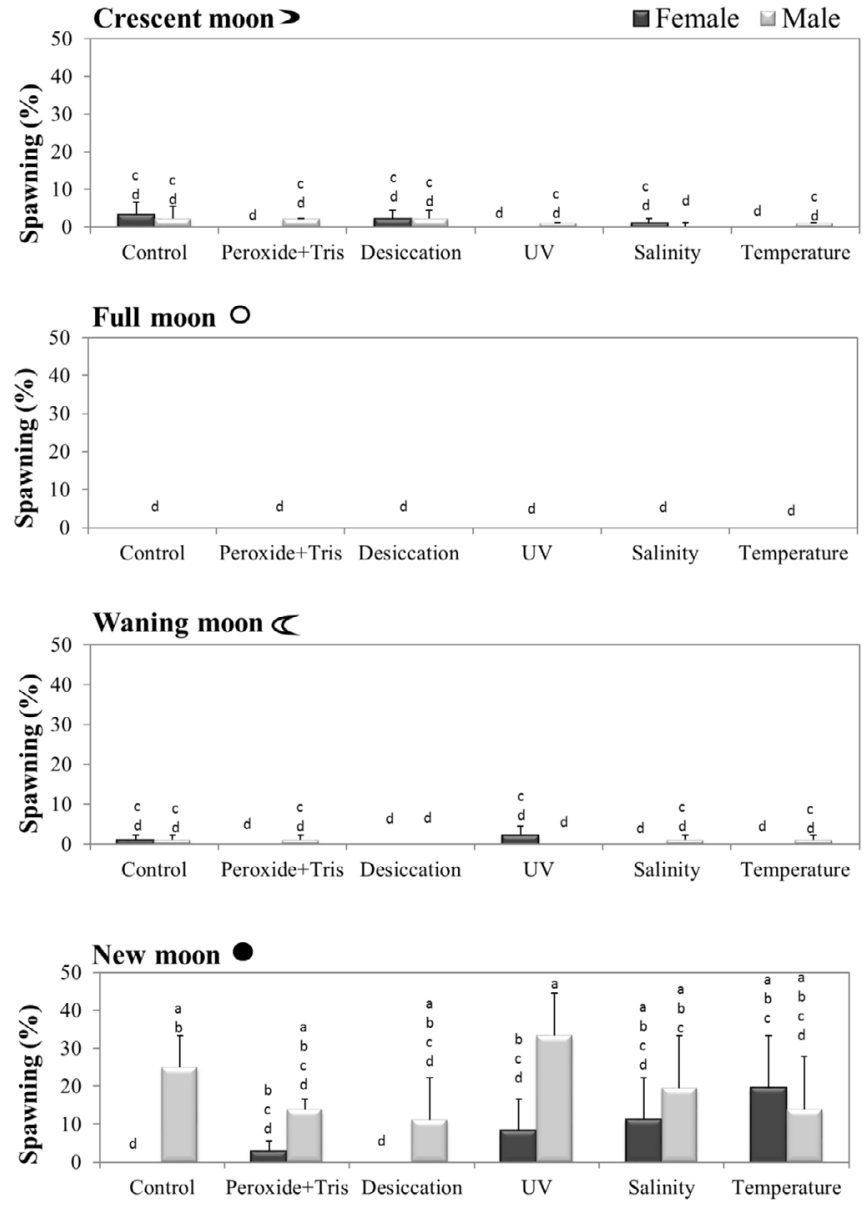

Spawning inducer

Fig. 2. Cittarium pica. Percentage of spawning individuals (male and female) in response to the application of different stimuli and moon phases. Values are means \pm S.E. $n>12$. Spawning inducers with the same case letters belong to a homogeneous group identified by the Bonferroni multiple range test. Significant differences existed among the groups $(p<0.05)$.

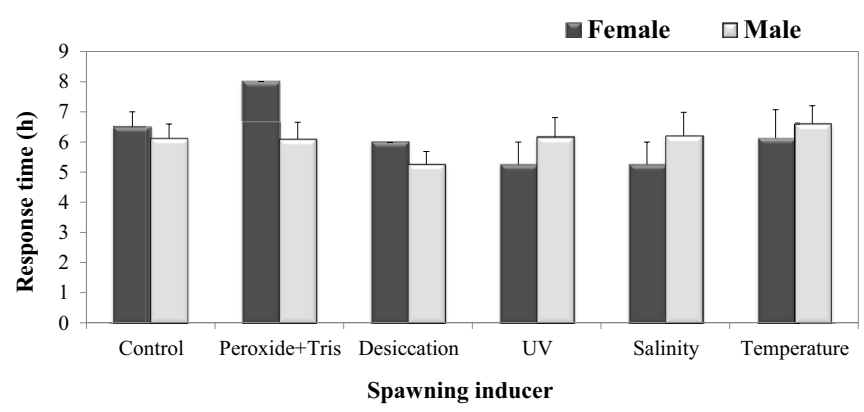

Fig. 3. Cittarium pica. Response time (h) to spawning stimulation. Values are means \pm S.E.

(Fig. 3). This variable was not significantly affected by sex $(\mathrm{df}=1, \quad F=0.06, p=0.8052), \quad$ spawning stimuli $\quad(\mathrm{df}=5$, $F=0.78, p=0.5697$ ), or the interaction among these factors $(\mathrm{df}=5, F=0.79, p=0.5662)$. 


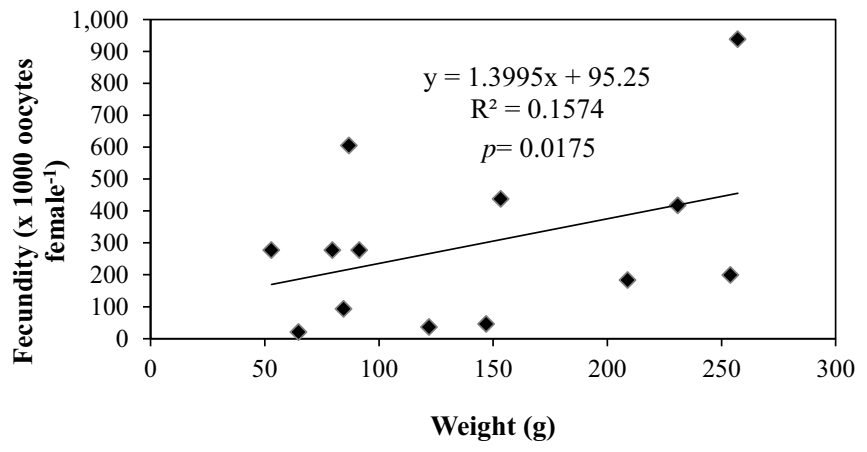

Fig. 4. Cittarium pica. Relationship between female wet live weight, shell length and its fecundity.

\subsection{Fecundity}

The number of oocytes released varied between 21500 and 469000 per female of $C$. pica ranging from 53 to $257 \mathrm{~g}$ of wet weight (56.6 and $91.2 \mathrm{~mm}$ of shell length) (Fig. 4). There was a significant positive linear relationship between fecundity and weight of the spawning females $\left(n=13, r^{2}=0.1574\right.$, $p=0.0175$ ). Intermittent spawning behavior of $C$. pica was observed; males and females released gametes once to three times within $28 \mathrm{~h}$. The wet weight of spawning males of $C$. pica varied between 48 and $302 \mathrm{~g}$ and shell length was between 65.8 and $103.8 \mathrm{~mm}$. Spawning males exhibited significantly higher values of weight and shell length than spawning females $(\mathrm{df}=1, \quad F=6.26, \quad p=0.0193 \quad$ and $\quad \mathrm{df}=1, \quad F=1924.48$, $p=0.0000$, respectively).

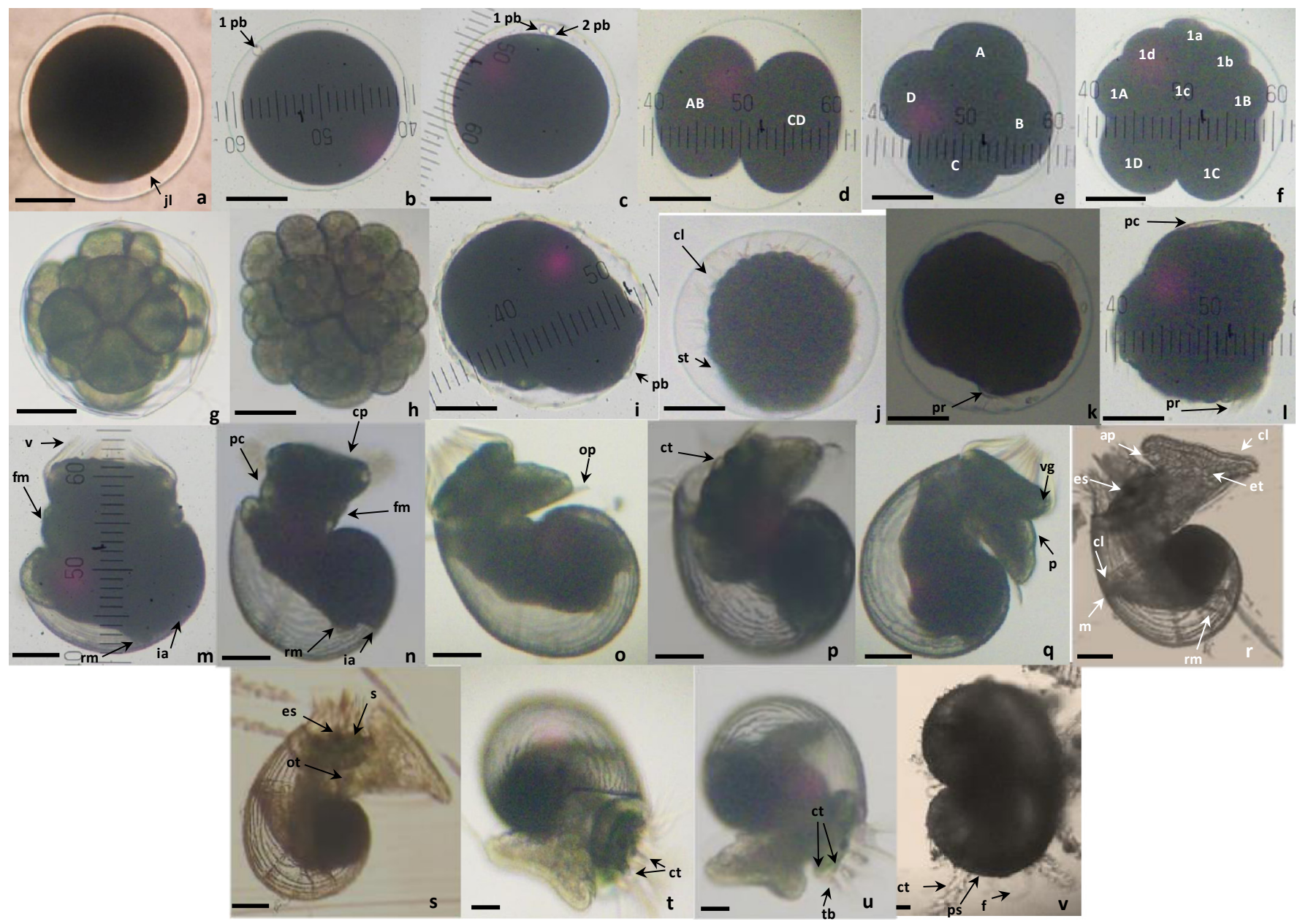

Fig. 5. Cittarium pica. Embryonic development in the first 97 days post-fertilization: (A) recently spawned oocyte with dissolved germinal vesicle and a jelly layer (j1). (B, C) Expulsion of polar bodies (pb). (D, E) First and second cleavages result in macromers (A, B, C and D) and micromers (a, b, c and d). (F, G) Third and fourth cleavages. (H) Morula. (I) Blastula. (J) Gastrula with cilia (cl) and stomodeum (st). (K) Intracapsular trochophore larvae with prototroch (pr). (L) Hatched trocophore with protoconch (pc). (M) Pre-torsional veliger with ciliated velum (v) and retractor muscle (rm). (N-S) Post-torsional veliger with foot mass (fm), integumental attachment (ia), operculum (op), cephalic tentacle (ct) and propodium (p), eye spot (es), cl in p and in mantle cavity (m), epipodial tentacles (et), apophysis (ap) on the p, otolith (ot) and snout protrusion (s). (T, U) Formation of two, three and four tubules (tb) in the ct. (V) Crawling veliger with foot (f). Bar size $=80 \mu \mathrm{m}$. 
Table 1. Early development of Cittarium pica. Time of appearance and size at various developmental stages.

\begin{tabular}{lcl}
\hline Development phase & Size $(\mu \mathrm{m})$ & Time \\
\hline Unfertilized oocyte & $180 \pm 5$ & 0 \\
First polar body & $185 \pm 4$ & $10 \mathrm{~min}$ \\
Second polar body & $185 \pm 4$ & $15 \mathrm{~min}$ \\
First cleavage & $200 \pm 6$ & $20 \mathrm{~min}$ \\
Second cleavage & $210 \pm 5$ & $40 \mathrm{~min}$ \\
Third cleavage & $212 \pm 3$ & $1.4 \mathrm{~h}$ \\
Morula & $215 \pm 7$ & $3.6 \mathrm{~h}$ \\
Blastula & $220 \pm 8$ & $4.4 \mathrm{~h}$ \\
Gastrula & $223 \pm 4$ & $5.4 \mathrm{~h}$ \\
Intracapsular trocophore & $226 \pm 6$ & $6.2 \mathrm{~h}$ \\
Hatched trocophore & $230 \pm 9$ & $9.7 \mathrm{~h}$ \\
Pre-torsional veliger & $241 \pm 19$ & $16 \mathrm{~h}$ \\
Post-torsional veliger & $260 \pm 14$ & $24 \mathrm{~h}$ \\
Crawling veliger & $271 \pm 3$ & $72 \mathrm{~h}$ \\
Spat & $1200 \pm 200$ & $48 \mathrm{days}$ \\
\hline
\end{tabular}

\subsection{Embryonic and early development}

Figure 5 illustrates the various stages in the development of C. pica and Table 1 lists the developmental time and size of the main stages during embryonic and early development. Oocytes were benthic, had a spherical shape, dark green color and an external jelly layer (jl) (Fig. 5a). Fertilization was followed by the formation of first and second polar bodies (pb) (Fig. 5b, c). After that, eggs underwent successive holoblastic and dextral spiral-type segmentation. The first and second cleavages were along the vertical axis and produced 2 and 4 similar size blastomeres, respectively (Fig. $5 \mathrm{~d}$, e). The third cleavage was along the horizontal plane, above the axis, resulting in embryos with 4 macromeres in the vegetal pole $(1 \mathrm{~A}, 1 \mathrm{~B}, 1 \mathrm{C}$ and $1 \mathrm{D})$ and 4 micromeres in the animal pole (1a, 1b, 1c and 1d) (Fig. 5f). The fourth unequal cleavage formed a 16-cell embryo (Fig. $5 \mathrm{~g}$ ). Later divisions gave rise to the morula (Fig. 5h) and blastula stages (Fig. 5i). Gastrulae were covered by cilia (cl), had a stomodeum (st) (Fig. 5j) and exhibited circular movements over their own axis, inside the egg membrane. Thereafter, an intra-capsular trochophore larva was formed, provided with a prototroch (pr) (Fig. 5k). Hatching of the swimming trochophore larvae occurred within $10 \mathrm{~h}$ postfertilization. Hatched trochophore was planktonic, positively phototactic, and had a dorsal protoconch (pc) with shell secretion (Fig. 5l). At 16h, the planktonic and lecitotrophic veliger larva was formed. The pre-torsional veliger had a flattened apical region, ciliated bi-lobed velum (v), retractor muscle (rm), integumental attachment (ia) and irregular broken spiral striations in the pc (Fig. $5 \mathrm{~m}$ ). Following this, protrusion of foot mass (fm), completion of the pc, $90^{\circ}$ and torsion of cephalo-pedal mass (cp) were noted (Fig. 5n). After that, the $180^{\circ}$ post-torsional veliger larvae with the operculum (op) (Fig. 5o), cephalic tentacles (ct) (Fig. 5p), vertical groove (vg) in the v, propodium (p) (Fig. 5q), eye spot (es), cl in the p and in the mantle cavity, apophysis (ap) on the p, epipodial tentacles (et) (Fig. 5r), otolith (ot) and snout protrusion (s) (Fig. 5s) and formation of two tubules in the ct (Fig. 5t) were noted. The crawling pediveliger was evident by the creeping behavior, the big foot (f) and the development of three and four tubules in the ct (Fig. 5u), and the spat were noted by the lack of v, and a longer and peristomal shell (ps) (Fig. 5v).

\section{Discussion}

\subsection{Spawning}

The association found between the spawning response of C. pica with daytime, new moon, flooding and high tides under ex-situ conditions suggests that spawning of the species is under circa-lunar and circadian endogenous regulation. These findings support in part the lunar spawning periodicity previously reported for this species in the Bahamas (Bell, 1992) and provide new insights on the influence of the time of day and tides on the regulation of spawning in C. pica. In other tropical vetigastropods such as Haliotis asinina (Singhagraiwan and Doi, 1992; Jebreen et al., 2000; Counihan et al., 2001), Haliotis varia (Najmudeen and Victor, 2004) and $T$. niloticus (Heslinga and Hillmann, 1981; Dwiono et al., 1997; Hanh, 1989c; Dobson, 1997), similar lunar and/or tidal spawning patterns have been reported but at nighttime. Nighttime with springtides is favored for spawning by broadcast spawners, especially gastropods, probably because they provide protection from predation and increased dispersal (Berry, 1986). In C. pica, the flooding and high tide spawning can promote gamete convergence through the coastline and favors oocyte fertilization, while the dark green color and benthic behavior of oocytes and embryos can provide good camouflage during the daytime. Also, daytime spawning at new moon can synchronize larval hatching (after $10 \mathrm{~h}$ ) with the darkest time and the highest reflux stream, increasing larval dispersion and avoidance of planktonic and pelagic predators.

The lack of spontaneous and induced spawning response in adults of $C$. pica maintained under ex-situ outdoor reproductive conditioning for more than 10 days and until one year, suggests that the endogenous spawning rhythm and/or the gonadal ripeness of the animals were lost in the absence of the in-situ conditions. For several species, induced spawning has proved more successful for animals exposed to at least one month of conditioning rather than for freshly caught wild broodstock (Morse, 1984; Hanh, 1989a; Setyono, 2004, 2006). In addition, the endogenous synchronous spawning pattern remains up to 6 weeks in $H$. asinina under ex-situ conditions, after which it shows asynchronous spawning events (Counihan et al., 2001). Quality and quantity of food, photoperiod, and water quality are important factors in gastropod gametogenic activity (Webber, 1977; Hanh, 1989d; Leighton, 2008). Although the specimens used in this study showed relatively high survival values, it is possible that the food or water quality conditions provided were suboptimal for their gonadic development. Alternatively, considering that C. pica is an intertidal species, exposure to the tidal regime may be essential to maintain the cyclic spawning pattern, as has been suggested for T. niloticus, in which continuous seed production is based on a monthly wild adult collection scheme (Hanh, 1989c).

The similarity in the spawning percentage and time of spawning responses between $C$. pica adults subjected to 
physical or chemical stimulation and the control animals indicates a lack of effect of these exogenous stimuli on the spawning response. Similar results have previously been reported in the tropical vetigastropods $H$. asinina (Setyono, 2006) and T. niloticus (Dobson, 1997). On the other hand, subtropical and temperate vetigastropods such as Haliotis coccinea canariensis, Haliotis fulgens, Haliotis discus hannai, Haliotis iris, Haliotis midae, Haliotis rufescens and Haliotis tuberculata spawn in response to this type of exogenous stimulation, mainly using hydrogen peroxide (Morse et al., 1977; Morse, 1984; Peña, 1986; Moss et al., 1995), which promotes the enzymatic synthesis of gonadic prostaglandin hormones (Morse et al., 1977; Osada and Nomura, 1990). As a result, it is possible that prostaglandin biosynthesis in C. pica and some other tropical vetigastropods is mainly under endogenous control rather than exogenous regulation, as a more efficient mechanism for spawning timing in tropical habitats with relatively high environmental stability.

The higher percentage of spawning males of $C$. pica compared to that of females is in accordance with findings observed in H. iris (Moss et al., 1995) and T. niloticus (Heslinga and Hillmann, 1981). This could be attributed to differences in the proportion of mature animals, reproductive cycle or relative abundance of both sexes. In natural populations of $C$. pica, a similar reproductive cycle for males and females is reported, with a sex ratio of 1:1 (Osorno and Díaz, 2006), as well as a higher proportion of males than females with mature gonads (Osorno, 2005). In several prosobranchs, testicles with mature gametes throughout the year have been recorded, while mature gametes in the ovaries have been found only periodically (Webber, 1977). In this case, the higher proportion of males of $C$. pica spawned could be attributed to the greater proportion of mature males in the natural populations.

The percent spawning responses obtained for $C$. pica in this study $(0-33 \%)$ were similar or lower than those reported in other vetigastropods such as $H$. asinina (0-100\%, Setyono, 2006), Haliotis laevigata (37-88\%, Babcock and Keesing, 1999; Grubert and Ritar, 2005), Haliotis rubra (43-97\%, Grubert and Ritar, 2005) and T. niloticus (0-83\%, Isa et al., 1997). Percent spawning mainly depends on the gonadic ripeness of the animals used as broodstock. The probability of obtaining ripe $C$. pica from the wild is low, due to the lack of externally visible gonad and the nature of its continuous reproductive cycle. A large proportion of immature animals $(>55 \%)$ are always present throughout the year in the adult samples of the Santa Marta populations (Osorno and Díaz, 2006).

The similarity in the timing of the first spawning response of males and females suggests strong spawning synchronization in C. pica. Results are similar to those found in $\mathrm{H}$. rubra (Ritar and Elliot, 2004; Grubert and Ritar, 2005) but differ from the earlier spawning responses reported for males in $T$. niloticus (Heslinga and Hillman, 1981), H. coccinea canariensis (Peña, 1986), H. iris (Moss et al., 1995) and Haliotis australis (Moss, 1998). The delay in the spawning of females is considered an adaptation to ensure the presence of sperm in water when oocytes are released (Fallu, 1991). However, it is known that once sperm and eggs are released in the water, fertilization success decreases with aging of gametes, especially when gametes are more diluted (Babcock and Keesing, 1999). Considering the low density of natural populations of $C$. pica (Osorno et al., 2009), the observed strong endogenous synchronization of male and female spawning could potentially be a better strategy to ensure fertilization success than that of early male spawning.

The repeated spawning of some individuals of $C$. pica within a single day and up to $28 \mathrm{~h}$ is similar to the behavior reported for other species such as $H$. asinina (Counihan et al., 2001; Setyono, 2006), H. laevigata, H. rubra (Grubert and Ritar, 2005), Tegula rustica (Kulikova and Omel'yanenko, 2000) and T. niloticus (Dwiono et al., 1997). This phenomenon may be related to the fact that in the gonad, the gametes can mature at different time (Webber, 1977; Kulikova and Omel'yanenko, 2000). Therefore, results suggest that $C$. pica is an intermittent or partial spawner.

The higher values of average size and weight of spawning males of $C$. pica $(84 \mathrm{~mm}$ shell length and weight $231 \mathrm{~g}$ live total) compared to spawning females $(75 \mathrm{~mm}$ shell length and $143 \mathrm{~g}$ of total body weight) is consistent with the higher average size of sexual maturity in males than in females of this species in the Santa Marta region (Osorno and Díaz, 2006). This could be attributed to the presence of some degree of protogynous hermaphroditism in the population, or to a sexual dimorphism due to higher growth in males than females. In vetigastropods, there are several reports on protandrous, simultaneous and alternating hermaphroditism (Webber, 1977), but none known at the time of writing about protogyny. On the other hand, in prosobranchs such as Olivella biplicata, differential growth of males and females has been verified (Edwards, 1968). It is therefore more probable that males have higher growth rates than females.

\subsection{Fecundity}

The positive linear relationship found between the weight of females and their fecundity is consistent with that found in other vetigastropods such as $H$. coccinea canariensis (Peña, 1986), H. midae (Wood and Buxton, 1996), H. rubra (Litaay and De Silva, 2003), $H$. rufescens (Molina, 1983) and $H$. tuberculata (Clavier, 1992). Gastropods of greater body size and age assign more energy to gonadal development (Hughes and Roberts, 1980; Estoy et al., 2002). For this reason, it is equally efficient to use a small number of larger individuals or a greater number of smaller animals, in terms of number of eggs produced.

The fecundity values found in this study for C. pica (22$469 \times 10^{3}$ oocytes female ${ }^{-1}$ ) are similar to those reported for tropical vetigastropods such as $H$. asinina $(66-163 \times$ $10^{3}$ oocytes female $^{-1} ;$ Setyono, 2006), H. ovina $\left(100-382 \times 10^{3}\right.$ oocytes female ${ }^{-1}$; Minh, 1997), H. tuberculata coccinea (86$691 \times 10^{3}$ oocytes female $^{-1}$; Bilbao et al., 2010), H. varia $\left(77 \times 10^{3}\right.$ oocytes female $^{-1}$; Najmudeen and Victor, 2004) and T. niloticus $\left(85-745 \times 10^{3}\right.$ oocytes female $^{-1}$; Isa et al., 1997). But these fecundities are lower than subtropical and temperate species such as $H$. iris $\left(945 \times 10^{3}\right.$ oocytes female ${ }^{-1}$; Moss et al., $1995)$, H. laevigata $\left(320-1600 \times 10^{3}\right.$ oocytes female ${ }^{-1}$; Grubert and Ritar, 2005), H. mariae (590-2800 $\times 10^{3}$ oocytes female $^{-1}$; Al-Rashdi and Iwao, 2008), H. midae $\left(590 \times 10^{3}\right.$ oocytes female $^{-1}$; Wood and Buxton, 1996), H. rubra $(109-7500 \times$ $10^{3}$ oocytes female $^{-1}$; Litaay and De Silva, 2003; Grubert and Ritar, 2005), and $H$. rufescens (180-30000 $\times 10^{3}$ oocytes female $^{-1}$; Giorgi and De Martini, 1977; Molina, 1983). This 
could be related to the more extended reproductive cycle in tropical vetigastropods, distributing the reproductive effort throughout a higher number of spawning events per year than those of higher latitudes.

\subsection{Early ontogenetic development}

The embryonic development of $C$. pica described in this study was very similar to that previously reported for this species (Bell, 1992), as well as for other vetigastropods such as Calliostoma ligatum (Holyoak, 1988), H. discus hannai (Hanh, 1989b), H. tuberculata coccinea (Courtois De Viçose et al., 2007), H. varia (Najmudeen and Victor, 2004), Lithopoma undosa (Salas-Garza et al., 2009), Tegula eiseni (Guzmán del Próo et al., 2011), Tegula funebralis (Moran, 1997), T. rustica (Kulikova and Omel'yanenko, 2000) and $T$. niloticus (Heslinga and Hillmann, 1981). However, new details about the development of $C$. pica such the segmentation process and the formation of larval specific structures such as the retractor muscle, integumental attachment, epipodial tentacles, apophysis on the propodium, otolith, snout protrusion, cephalic tentacles and its tubules are included in this study. The thick layer of gelatinous material previously reported for the same species (Bell, 1992) was not observed here, most likely due to the fact that this layer can easily degrade in warm water (Isa et al., 1997).

The rate of development of $C$. pica was lower than that of other tropical species such as H. asinina, H. ovina (Jarayabhand and Paphavasit, 1996) and T. niloticus (Heslinga and Hillmann, 1981), where crawling veliger larvae appear before 3 days. However, the $C$. pica development rate was higher than that of temperate and subtropical species such as Crepidula fornicata (Pechenik, 1984), H. corrugata (Leighton, 1974), H. midae (Genade et al., 1988), H. mariae (Al-Rashdi and Iwao, 2008), $H$. tuberculata (Koike, 1978), Gibbula cirenaria (Underwood, 1972), L. undosa (Salas-Garza et al., 2009), T. eiseni (Guzmán del Próo et al., 2011), T. funebralis (Moran, 1997) and T. rustica (Kulikova and Omel'yanenko, 2000), where crawling larvae developed 4 days after fertilization.

\section{Conclusion}

In summary, there is a high potential to use controlled exsitu reproduction of C. pica as a conservation tool of this important Caribbean snail, since gamete and larvae were repeatedly obtained from wild adults collected some days before new moon, following a circadian endogenous pattern using simple protocols of spawning, fertilization and incubation. Additional research about the requirements for broodstock conditioning such as food and water quality is needed in order to improve ex-situ reproduction success.

Acknowledgements. The authors thank L. Pabón, A. Narvaez, G. Blanco, T. Imamura and the staff of the Laboratory of Mollusks and Microalgae of the Universidad del Magdalena for their help during the experiments. The authors also thank S. Sarkis for her language and editorial corrections. This study was supported by Projects COLCIENCIAS 1117-521-28882 and FONCIENCIAS 037-2010/22-2016, and was performed under CORPAMAG research permits 761 of $05 / 18 / 2010$ and 670 of $03 / 28 / 2012$.

\section{References}

Al-Rashdi KM, Iwao T. 2008. Abalone, Haliotis mariae (Wood, 1828), hatchery and seed production trials in Oman. J Agric Mar Sci 13: 53-63.

Ardila NE, Navas GR, Reyes JO. 2002. Libro rojo de invertebrados marinos de Colombia. Colombia: INVEMAR, 177 p.

Babcock R, Keesing J. 1999. Fertilization biology of the abalone Haliotis laevigata: laboratory and field studies. Can J Fish Aquat Sci 56: 1668-1678.

Bell L. 1992. Reproduction and larval development of the West Indian top shell, Cittarium pica (Trochidae) in the Bahamas. Bull Mar Sci 51(2): 250-266.

Berry AJ. 1986. Daily, tidal, and two-weekly spawning periodicity and brief pelagic dispersal in the tropical intertidal gastropod Umbonium vestiarium (L.). J Exp Mar Biol Ecol 95(3): 211-223.

Bilbao A, Tuset V, Viera MP, et al. 2010. Reproduction, fecundity, and growth of abalone (Haliotis tuberculata coccinea, Reeve 1846) in the Canary Islands. J Shellfish Res 29(4): 959-967.

Chen HC. 1984. Recent innovations in cultivation of edible molluscs in Taiwan, with special reference to the small abalone Haliotis diversicolor and the hard clam Meretrix lusoria. Aquaculture 39: $11-27$.

Clare AS. 1990. Laboratory-induced spawning of the gastropod Gibbula cineraria as an indicator of field spawning. Mar Ecol Prog Ser 63: 303-304.

Clarke PJ, Komatsu T, Bell JD, Lasi F, Oengpepa CP, Leqata J. 2003. Combined culture of Trochus niloticus and giant clams (Tridacnidae): benefits for restocking and farming. Aquaculture 215: $123-44$.

Clavier J. Fecundity and optimal sperm density for fertilization in the ormer, Haliotis tuberculata L. In: Shepherd SA, Tegner MJ, Guzmán del Próo SA, eds. Abalone of the world: biology, fisheries and culture. Oxford: Fishing News Books, 1992, pp. 86-92.

Counihan RT, McNamara DC, Souter DC, et al. 2001. Pattern, synchrony and predictability of spawning of the tropical abalone Haliotis asinina from Heron Reef, Australia. Mar Ecol Prog Ser 213: 193-202.

Courtois De Viçose GC, Viera MP, Bilbao A, Izquierdo MS. 2007. Embryonic and larval development of Haliotis tuberculata coccinea Reeve: an indexed micro-photographic sequence. $J$ Shellfish Res 26(3): 847-854.

Debrot A. 1990. Temporal aspects of population dynamics and dispersal behavior of the West Indian topshell, Cittarium pica (L.), at selected sites in the Exuma Cays, Bahamas. Bull Mar Sci 47(2): 431-447.

Dobson G. 1997. Preliminary studies of the induced spawning of Trochus niloticus (Linnaeus) using artificial stimuli. In: Lee CL, Lynch PW, eds. Trochus: status, hatchery practice and nutrition, Canberra, Australia, Proceedings of a workshop held at Northern Territory University, ACIAR Proceedings No. 79, pp. 60-63.

Dwiono SAP, Makatipu PC, Pradina. 1997. A hatchery for the topshell (T. niloticus) in eastern Indonesia. In: Lee CL, Lynch PW, eds. Trochus: status, hatchery practice and nutrition, Canberra, Australia, Proceedings of a workshop held at Northern Territory University, ACIAR Proceedings No. 79, pp. 33-37.

Edwards DC. 1968. Reproduction in Olivella biplicata. Veliger 10(4): 267-304.

Estoy GF, Yusa Y, Wada T, Sakurai H, Tsuchida K. 2002. Effects of food availability and age on the reproductive effort of the apple snail, Pomacea canaliculata (Lamarck) (Gastropoda: Ampullariidae). Appl Entomol Zool 37(4): 543-550. 
Fallu R. 1991. Abalone farming. London, Oxford: Fishing News Books.

Genade AB, Hirst AL, Smit CJ. 1988. Observations on the spawning and rearing of the South African abalone Haliotis midae Linn. Knysna, South Africa: Fisheries Development Corporation.

Giorgi AE, De Martini JD. 1977. A study of the reproductive biology of the red abalone, Haliotis rufescens Swainson, near Mendocino, California. Calif Fish Game 63(2): 80-94.

Grubert MA, Ritar AJ. 2005. The effect of temperature and conditioning interval on the spawning success of wild-caught blacklip (Haliotis rubra, Leach 1814) and greenlip (H. laevigata, Donovan 1808) abalone. Aquac Res 36: 654-665.

Guillard RRL. Culture of phytoplankton for feeding marine invertebrates. In: Smith WL, Chanley $\mathrm{MH}$, eds. Culture of marine invertebrate animals. New York: Plenum Publishers, 1975, pp. 29-66.

Guzmán del Próo SA, Reynoso-Granados T, Serviere-Zaragoza E, Monsalvo-Spencer P. 2011. Larval and early juvenile development of Tegula eiseni (Jordan, 1936) (Gastropoda: Trochidae). CICIMAR Oceán 26(1): 43-50.

Hanh KO. Artificial induction of spawning and fertilization. In: Hanh $\mathrm{KO}$, ed. Handbook of culture of abalone and other marine gastropods. Boca Raton, FL, USA: CRC Press, Inc., 1989a, pp. 53-70.

Hanh KO. Larval development of abalone. In: Hanh KO, ed. Handbook of culture of abalone and other marine gastropods. Boca Raton, FL, USA: CRC Press, Inc., 1989b, pp. 71-99.

Hanh KO. Cultural of the tropical top shell Trochus niloticus. In: Hanh KO, ed.Handbook of culture of abalone and other marine gastropods. Boca Raton, FL, USA: CRC Press, Inc., 1989c, pp. 301-315.

Hanh KO. Artificial induction of conditioning (gonad maturation). In: Hanh KO, ed. Handbook of culture of abalone and other marine gastropods. Boca Raton, FL, USA: CRC Press, Inc., 1989d, pp. 101-112.

Heslinga GA, Hillmann A. 1981. Hatchery culture of the commercial top snail Trochus niloticus in Palau, Caroline Islands. Aquaculture 22: 35-43.

Holyoak AR. 1988. Spawning and larval development of the trochid gastropod Calliostoma ligatum (Gould, 1849). Veliger 30: 369-371.

Hughes R, Roberts D. 1980. Reproductive effort of winkles (Littorina spp.) with contrasted methods of reproduction. Oecologia 47: $130-136$

IDEAM. 2009. Servicio mareográfico, Pronóstico de pleamares y bajamares en la costa Caribe colombiana, Año 2010.

IDEAM. 2011. Servicio mareográfico, Pronóstico de pleamares y bajamares en la costa Caribe colombiana, Año 2012.

Isa J, Kubo H, Murakoshi M. 1997. Mass seed production and restocking of Trochus in Okinawa. In:Workshop on Trochus Resource Assessment, Management and Development: Report and selected papers, Noumea, New Caledonia, Integrated Coastal Fisheries Management Project Technical Document No. 13. South Pacific Commission, pp. 75-99.

Jarayabhand P, Paphavasit N. 1996. A review of the culture of tropical abalone with special reference to Thailand. Aquaculture 140: $159-168$.

Jebreen JE, Counihan BT, Fielder DR, Degnan BM. 2000. Synchronous oogenesis during the semilunar spawning cycle of the tropical abalone Haliotis asinina. J Shellfish Res 19: 845-851.

Kikuchi S, Uki N. 1974. Technical study on artificial spawning of abalone, genus Haliotis II. Effect of irradiated sea water with ultraviolet rays on inducing to spawn. Bull Tohoku Reg Fish Res Lab 33: 79-86.
Koike Y. 1978. Biological and ecological studies on the propagation of the ormer, Haliotis tuberculata Linnaeus. I: larval development and growth of juveniles. La Mer 16(3): 124-136.

Kulikova VA, Omel'yanenko VA. 2000. Reproduction and larval development of the gastropod mollusk Tegula rustica in Peter the Great Bay, Sea of Japan. Russ J Mar Biol 26 (2): 128-130.

Leighton DL. 1974. The influence of temperature on larval and juvenile growth in three species of southern California abalones. Fish Bull 72(4): 1137-1145.

Leighton P. 2008. Abalone Hatchery Manual. Aquaculture Explained, Abalone File No. 25.

Litaay M, De Silva SS, 2003. Spawning season, fecundity and proximate composition of the gonads of wild-caught blacklip abalone (Haliotis rubra) from Port Fairy waters, south eastern Australia. Aquat Living Resour 16(4): 353-361.

Minh LD. 1997. Reproductive cycle of Haliotis ovina Gmelin, 1791 in Nha Trang bay, South central Vietnam. Phuket Mar Biol Cent Spec Publ 19(1): 51-53.

Molina J. 1983. Estimaciones de fecundidad en Haliotis rufescens de El Bajo, Bahía Rosario, Baja California. Cienc Pesq 4: 77-95.

Moran AL. 1997. Spawning and larval development of the black turban snail Tegula funebralis (Prosobranchia: Trochidae). Mar Biol 128: 107-114.

Morse DE. 1984. Biochemical and genetic engineering for improved production of abalones and other valuable molluscs. Aquaculture 39: 263-282.

Morse DE, Duncan H, Hooker N, Morse A. 1977. Hydrogen peroxide induces spawning in mollusks, with activation of prostaglandin endoperoxide synthetase. Science 196: 298-300.

Moss GA. 1998. Effect of temperature on the breeding cycle and spawning success of the New Zealand abalone, Haliotis australis. N Z J Mar Freshw Res 32: 139-146.

Moss GA, Illingworth J, Tong LJ. 1995. Comparing two simple methods to induce spawning in the New Zealand abalone (paua), Haliotis iris. N Z J Mar Freshw Res 29(3): 329-333.

Najmudeen TM, Victor ACC. 2004. Seed production and juvenile rearing of the tropical abalone Haliotis varia Linnaeus 1758. Aquaculture 234: 277-292.

Onitsuka T, Kawamura T, Horii T. 2010. Reproduction and early life ecology of Abalone Haliotis diversicolor in Sagami Bay, Japan. JARQ 44(4): 375-382.

Onitsuka T, Kawamura T, Horii T, Takiguchi N, Takami H, Watanabe Y. 2007. Synchronized spawning of abalone Haliotis diversicolor triggered by typhoon events in Sagami Bay, Japan. Mar Ecol Prog Ser 351: 129-138.

Osada M, Nomura T. 1990. The levels of prostaglandins associated with the reproductive cycle of the scallop, Patinopecten yessoensis. Prostaglandins 40(3): 229-239.

Osorno A. 2005. Bioecología de la "cigua" o "burgao" Cittarium pica (linnaeus, 1758) (Mollusca: Gastropoda: Trochidae) en la costa continental del Caribe colombiano (Bas. Tesis). Santa Marta, Colombia: Univ. Jorge Tadeo Lozano.

Osorno A, Díaz JM. 2006. Explotación, usos y estado actual de la cigua o burgao Cittarium pica (Mollusca: Gastropoda: Trochidae) en la costa continental del Caribe colombiano. Bol Investig Mar Costeras 35: 133-148.

Osorno A, Díaz JM. 2009. Aspectos reproductivos del burgao Cittarium pica en los litorales rocosos de Santa Marta y Parque Nacional Natural Tayrona, Caribe colombiano, con énfasis en su conservación y aprovechamiento sostenible. In: Osorno A, GilAgudelo DL, Gómez-Lemos LA, eds. Plan de Investigación para la Conservación de Cittarium pica (Linnaeus, 1758). Santa Marta, 
Colombia: INVEMAR, Serie de Publicaciones Especiales No. 16, pp. 55-59.

Osorno A, Gil D. 2009. Explotación, abundancia y estado de wilks Cittarium pica (Linnaeus, 1758) (Mollusca: Gastropoda Trochidae) en las islas de San Andrés, Providencia y Santa Catalina, último eslabón para conocer el estado de sus poblaciones en Colombia. Informe técnico final. Santa Marta, Colombia: INVEMAR, Conservación Internacional, UAESPNN y CORALINA.

Osorno A, Gil-Agudelo DL, Gómez-Lemos LA. 2009. Plan de Investigación para la Conservación de Cittarium pica (Linnaeus, 1758). Santa Marta, Colombia: INVEMAR, Serie de Publicaciones Especiales No. 16.

Osorno A, Sanjuan A. Epibiontes, fauna y flora acompañante de Cittarium pica (Mollusca: Gastropoda: Trochidae) (Linnaeus, 1758) en el litoral rocoso del Caribe colombiano. In Osorno A, Gil D, eds. Plan de Investigación para la Conservación de Cittarium pica (Linnaeus, 1758). Santa Marta, Colombia: INVEMAR, Serie de Publicaciones Especiales No. 16, 2009.

Pechenik JA. 1984. The relationship between temperature, growth rate, and duration of planktonic life for larvae of the gastropod, Crepidula fornicata (L.). J Exp Mar Biol Ecol 74(3): 241-257.

Peña JB. 1986. Preliminary study on the induction of artificial spawning in Haliotis coccinea canariensis Nordsieck (1975). Aquaculture 52: 35-41.

Preston SJ, Keys A, Roberts D. 2007. Culturing freshwater pearl mussel Margaritifera margaritifera: a breakthrough in the conservation of an endangered species. Aquat Conserv 17: 539-549.

Purcell SW, Cheng YW. 2010. Experimental restocking and seasonal visibility of a coral reef gastropod assessed by temporal modelling. Aquatic Biol 9: 227-238.

Randall H. 1964. A study of the growth and other aspects of the biology of the West Indian topshell, Cittarium pica (Linnaeus). Bull Mar Sci Gulf Caribb 14(3): 424-443.

Ritar AJ, Elliot NG. 2004. Abalone aquaculture subprogram: the commercial control of spawning in temperate abalone. FRDC Project No. 2000/204. Tasmanian Aquaculture and Fisheries Institute, University of Tasmania.

Robertson R. 2003. The edible West Indian "Whelk" Citarium pica (Gastropoda: Trochidae): natural history with new observations. Proc Acad Nat Sci Phila 153: 27-47.
Rosique J, Toro B, Marín JG, Galeano N, Correa T. 2008. Algunos lineamientos para la conservación de Cittarium pica en la costa Caribe del Darién colombiano. Bol Antropol 22(39): 314-334.

Salas-Garza A, Parés-Sierra G, Gómez-Rigalt R, Carpizo-Ituarte E. 2009. The larval development, metamorphosis and juvenile growth of the turban snail Lithopoma (Astraea) undosa (Wood, 1828) (Gastropoda: Turbinidae). JWAS 40(4): 460-471.

Setyono DED. 2004. Abalone (Haliotis asinina L.): 3. Induction of Spawning. Oseana 29(3): 17-23.

Setyono DED. 2006. Induction spawning for the Tropical Abalone (Haliotis asinina) in the laboratory. Indones Aquac J 1(1): 17-27.

Singhagraiwan T, Doi M. 1992. Spawning pattern and fecundity of the Donkey's ear abalone, observed in captivity. Thai Mar Fish Res Bull 3: 61-69.

Thomas GR, Taylor J, Garcia de Leaniz C. 2010. Captive breeding of the endangered freshwater pearl mussel Margaritifera margaritifera. Endanger Species Res 12: 1-9.

Toro B, Correa T, Marín JG, Rosique J. Algunos aspectos biológicos y socioculturales de la cigua (Citttarium pica) en el Golfo de Urabá. In: Osorno A, Gil D, eds. Plan de Investigación para la Conservación de Cittarium pica (Linnaeus, 1758). Santa Marta, Colombia: INVEMAR, Serie de Publicaciones Especiales No. 16, 2009.

Uki N, Kikuchi S. 1984. Regulation of maturation and spawning of an abalone, Haliotis (Gastropoda) by external environmental factors. Aquaculture 39: 247-261.

Underwood AI. 1972. Spawning, larval development and settlement behavior of Gibbula cineraria (Gastropoda: Prosobranchia) with a reappraisal of torsion in gastropods. Mar Biol 17: 341-349.

Vivas-Aguas LJ, Espinosa L, Sánchez J, et al. 2012. Diagnóstico y evaluación de la calidad ambiental marina en el Caribe y pacífico colombiano. Red de vigilancia para la conservación y protección de las aguas marinas y costeras de Colombia-REDCAM. Informe técnico 2012. Santa Marta, Colombia: INVEMAR.

Webber HH. Gastropoda: Prosobranchia. In: Giese C, Pearse JS, eds. Reproduction of marine invertebrates, vol. 4. New York: Academic Press Inc., 1977, pp. 1-95.

Wood AD, Buxton CD. 1996. Aspects of the biology of the abalone Haliotis midae (Linne, 1758) on the east coast of South Africa. 2. Reproduction. Afr J Mar Sci 17(1): 69-78.

Zar JH. 1999. Biostatistical analysis, 4th ed. London, UK: PrenticeHall.

Cite this article as: Velasco LA, Barros J. 2017. Spawning and early development of the West Indian top shell, Cittarium pica (Linnaeus, 1758), under ex-situ conditions. Aquat. Living Resour. 30: 22 